Tersedia online di http://ejournal-balitbang.kkp.go.id/index.php/jp
e-mail:jurnalpari@gmail.com
Jurnal Pari
Volume 2 Nomor 1 Juli 2016
-ISSN : 2502-0730
e-ISSN : 2549-0133

\title{
PERANAN PUSTAKAWAN DALAM MENDUKUNG KNOWLEDGE MANAJEMEN REPOSITORY KEMENTERIAN KELAUTAN DAN PERIKANAN
}

\section{LIBRARIAN ROLE TO SUPPORT MANAGEMENT KNOWLEDGE REPOSITORY MINISTRY OF MARINE AFFAIRS AND FISHERIES (MMAF)}

\author{
Nur Rahayu \\ Pusat Penelitian dan Pengembangan Daya Saing Produk Dan Bioteknologi Kelautan dan Perikanan \\ Diterima tanggal : 9 Mei 2016 Diterima setelah perbaikan : 17 Juni 2016 \\ disetujui terbit : 8 Juli 2016
}

\begin{abstract}
ABSTRAK
Knowledge repository Kementrian Kelautan dan Perikanan (KKP) bertujuan untuk menjaring informasi yang telah dihasilkan oleh KKP sebagai local content yang akan dijadikan sumber rujukan utama informasi Kelautan dan Perikanan di Indonesia. Dalam membangun Knowledge repository maka peran pustakawan sangat besar dalam menjaring informasi local content dan mengolahnya secara digital. Peran pustakawan sangat dipengaruhi oleh kompetensi yang dimiliki oleh pustakawan dan juga kondisi perpustakaan sebagai tempat pustakawan bekerja. Perpustakaan sebagai institusi pengolah informasi sangat besar pengaruhnya terhadap kinerja pustakawan dalam meningkatkan peran perpustakaan sebagai knowledge repository. Kondisi perpustakaan di lingkup KKP pada saat ini secara struktural kedudukannya masih rendah dan juga belum memenuhi Standar Nasional Indonesia (SNI) tentang penyelenggaraan perpustakaan di lingkup Instansi Pemerintah. SNI tentang perpustakaan ini telah diadopsi oleh KKP dalam bentuk Permen KP No.8 2014 tentang penyelenggaraan perpustakaan di lingkup KKP namun belum diimplentasikan secara optimal. Agar Pustakawan lebih berperan dalam mendukung Knowledge Repository KKP, maka perlu dilakukan optimalisasi pelaksanaan Permen KP No.8 Tahun 2014, dan meningkatkan kedudukan perpustakaan secara struktural di seluruh unit kerja/satker di lingkup KKP.
\end{abstract}

Kata Kunci : Pengetahuan Repository; Peranan Pustakawan; Perpustakaan KKP, Peraturan Menteri Kelautan dan Perikanan No. 8 Tahun 2014

\begin{abstract}
Knowledge repository Ministry of Marine Affairs and Fisheries (MMAF) aims to capture the information that has been generated by the MMAF as local content that will be the main reference source of information on the Indonesian Marine and Fisheries. In building the Knowledge repository, the role of librarians is very large in capturing local content and process information digitally. The role of librarians is strongly influenced by the competencies possessed by librarians and library conditions as a place to work. Library as an institution of information processing has very large influence on the performance of librarians in enhancing the role of the library as a knowledge repository. The Conditions of libraries in the scope of the MMAF at this time structurally position is still low and do not meet the Indonesian National Standard (SNI). SNI of the library has been adopted by the MMAF in the form of ministry regulations KP No.8 year 2014 on the administration of the library in the scope of MMAF. In order Librarians do more to support the MMAF Knowledge Repository, it is necessary to optimize the implementation of ministry regulations KP No.8 Year 2014, and improve the position of library as structurally in all work units / work units in the scope of the MMAF.
\end{abstract}

Keywords: Knowledge Repository ; Librarian role; MMAF Library; Ministry regulations KP No.8 year 2014

Korespondensi Penulis:

Jl. K.S Tubun Petamburan VI Jakarta 10260

Email : nurahayu54@gmail.com 


\section{PENDAHULUAN}

Sejak Kementerian Kelautan dan Perikanan didirikan telah banyak menghasilkan informasi terutama dari hasil penelitian, penyuluhan dan kebijakan/Peraturan yang dibuat dalam mendukung pembangunan di bidang kelautan dan perikanan. Pembangunan di bidang kelautan dan perikanan ditujukan untuk meningkatkan kesejahteraan masyarakat Indonesia utamanya para pelaku di bidang usaha kelautan dan perikanan, ilmuwan dan bidang lain yang terkait. Informasi yang telah dihasilkan harus diolah sebagai ilmu pengetahuan yang dapat disebarkan atau di akses dengan mudah oleh para penggunanya. Pengelolaan informasi sebagai ilmu pengetahuan pada saat ini dikenal sebagai knowledge Manajemen. Istilah knowledge manajemen (KM) yang menurut sebagian profesi informasi dan perpustakaan bukan lagi merupakan konsep baru, ada yang berpendapat bahwa knowledge manajemen atau dalam bahasa Indonesia sebagai manajemen pengetahuan (MP) adalah kemasan baru dari Manajemen Informasi (MI) yang selama ini merupakan tugas profesi pustakawan. Pengelolaan informasi menjadi ilmu pengetahuan dilakukan di perpustakaan. Perpustakaan sebagai tempat manajemen ilmu pengetahuan secara elektronik atau digital disebut perpustakaan digital atau repository. Repository berfungsi sebagai Tempat menyimpan Informasi yang dikumpulkan dari berbagai sumber informasi dan juga menjadi sumber referensi bagi para ilmuwan dan para pengguna lainnya. Semua fungsi diatas dilakukan oleh pustakawan karena itu, pustakawan sebaiknya mempunyai kemampuan yang cukup dalam hal pencarian, pengolahan dan kemas-ulang informasi serta kemampuan belajar secara cepat dan kemampuan berkomunikasi. Konsep Mekanisme (information access provider). Syarat mutlaknya adalah dengan menguasai Teknologi Informasi Komunikasi dan bahasa.

Knowledge repository Kementerian Kelautan dan Perikanan (KKP) bertujuan untuk menjaring informasi yang telan dihasilkan oleh KKP sebagai local content yang akan dijadikan sumber rujukan utama informasi perikanan dan kelautan di Indonesia. Dalam membangun Knowledge repository maka peran perpustakaan sebagai institusi pengolah informasi sangat besar begitu juga pustakawan sebagai pelaksanaan kegiatan di perpustakaan. Perpustakaan di pusat di KKP secara struktural kedudukanya masih rendah apalagi yang berada pada satker - satker di lingkup KKP yg tersebar di seluruh Indonesia. Kondisi perpustakaan dan pustakawannya juga sangat bervariasi antara perpustakaan yang sudah memenuhi standar SNI perpustakaan khusus dan yang masih jauh dari standar begitu juga dengan pustakawanya ada yang sudah menguasai IT dan ada yang belum. Dengan kondisi demikin ini tentunya akan menjadi kendala dalam penjaringan informasi sehingga perlu adanya keseragaman kondisi baik perpustakaan dan pustakawannya. Pusat data dan Informasi (PUSDATIN) sebagai instansi Pembina perpustakaan di KKP telah melakukan berbagai usaha untuk meningkatkan peran perpustakaan dan pustakawan antara lain dengan mengadakan bimbingan teknis kepada pustakawan dan penyusunan draf penyelenggaraan perpustakaan yang telah terbit dalam bentuk permen KP No.8 tahun 2014 tentang penyelenggaraan perpustakaan di lingkup KKP namun masih belum dilaksanakan secara optimal. Dengan mengoptimalkan pelaksanaaan permen KP No.8 tentang penyelengaraan perpustakaan di lingkup KKP dan meningkatkan kedudukan perpustakaan secara struktural baik di pusat maupun di daerah maka dapat diharapkan pustakawan akan lebih berperan dalam mendukung Knowledge Repository KKP.

\section{KNOWLEDGE MANAJEMEN}

Manajemen Pengetahuan (Inggris: Knowledge management) menurut definisi wikipewedia adalah kumpulan perangkat, teknik, dan strategi untuk mempertahankan, menganalisis, mengorganisasi, meningkatkan, dan membagikan pengertian dan pengalaman. Pengertian dan pengalaman semacam itu terbangun atas pengetahuan, baik yang terwujudkan dalam seorang individu atau yang melekat di dalam proses dan aplikasi nyata 
suatu organisasi. Fokus dari manajemen pengetahuan adalah menemukan cara-cara baru untuk menyalurkan data mentah ke bentuk informasi yang bermanfaat, hingga akhirnya menjadi pengetahuan. Knowledge Management juga dapat diartikan sebagai suatu rangkaian kegiatan yang digunakan oleh organisasi untuk mengidentifikasi, menciptakan, menjelaskan, dan mendistribusikan pengetahuan (transfer pengetahuan) untuk digunakan kembali, diketahui, dan dipelajari di dalam organisasi tersebut. Kegiatan ini terkait langsung dengan perpustakaan yang ditujukan untuk mencapai suatu hasil tertentu seperti pengetahuan bersama, peningkatan kinerja, keunggulan kompetitif, atau tingkat inovasi yang lebih tinggi. Sedangkan Transfer pengetahuan sebagai salah satu aspek dari Knowledge Management dalam berbagai bentuk, telah sejak lama dilakukan oleh perpustakaan. Contohnya adalah melalui Knowledge Sharing dalam kerja, magang, pelatihan profesional, workshop.

Secara singkat manajemen pengetahuan dapat diartikan sebagai serangkaian assetasset informasi. Asset informasi tersebut bisa terdiri dari, data base, dokumen, peraturanperaturan dll. Secara umum dapat dismpulkan bahwa knowledge manajemen adalah tehnik mengelola pengetahuan dalam organisasi untuk menciptakan nilai dan meningkatkan keunggulan kompetitif. Melalui penerapan Knowledge Management di perpustakaan maka akan terjadi proses komunikasi ilmiah yang dapat terus berkembang, karena inti dari knowledge manajemen adalah berbagi atau sharing pengetahuan. Dalam hal ini perpustakaan dapat mengambil peran sebagai pengumpul, pengolah, penyimpan dan penyebar pengetahuan yang telah dihasilkan oleh para peneliti, penyuluh dan pengambil kebijakan.dll.Dalam kegiatan perpustakaan manajemen pengetahuan adalah bukan hal baru karena aktivitas manajemen pengetahuan adalah aktivitas keseharian perpustakaan. Kegiatan pengorganisasian selalu diikuti dengan penyimpanan. Jika kegiatan dilakukan di tingkat organisasi, pengetahuan disimpan dalam penyimpanan pengetahuan (knowledge repository) misalnya: server, yang dapat diakses secara kolektif untuk pemanfaatan bersama. Adanya knowledge repository ini dan ketersediaan data di dalamnya merupakan prasyarat terjadinya pertukaran dan penggabungan pengetahuan yang memungkinkan terciptanya pengetahuan baru. Untuk individu biasanya proses ini dilakukan sendiri-sendiri dan tergantung pada individu yang melakukan proses. Biasanya pengetahuan disimpan dalam penyimpanan milik pribadi, misalnya harddisk komputer atau komputer sendiri dan USB

\section{PERPUSTAKAAN SEBAGAI KNOWLEDGE REPOSITORY}

Repository dalam bahasa Inggris (Echols dan Shadily, 1995: 479 kol. 1) berarti sebagai tempat penyimpan (an)/gudang, sedang menurut Kamus Besar IImu Pengetahuan (Dagun, 2005: 959, kol. 2) kata repository berasal dari bahasa Latin (repositoria atau repositorium) artinya tempat untuk menyimpan barang-barang berharga di dalam candi, di dalam gereja Romawi kuno dan lain lain. Berdasarkan arti kata menurut kamus tersebut repository secara sederhana diartikan sebagai tempat untuk menyimpan barang-barang berharga. Secara bahasa knowledge repository dapat diartikan sebagai tempat penyimpanan pengetahuan tapi dalam dunia perpustakaan pada saat ini diartikan sebagai perpustakaan digital. Repository (Perpustakaan Digital) Istilah perpustakaan digital atau repository mempunyai pengertian yang sama antara lain: Digital Library, Virtual Library, Electronic Library, Hybrid Library, dan Cyber Library.Pengertian Perpustakaan digital menurut Don WatersDirektur Digital Library Federation, Amerika (1998) adalah: "suatu organisasi atau Lembaga yang menyediakan sumber informasi termasuk penyiapan staff yang ahli dalam menyeleksi, mengolah, mengakses, menstruktur, menyebarkan, menginterpretasi, dan menyimpan berbagai hasil kerja koleksi berupa digital dan menyajikannya secara ekonomis untuk keperluan masyarakat sebagai penggunannya. 
Perpustakaan sebagai knowledge repository sebetulnya sudah sama dengan yang dimaksud oleh Undang-undang Republik Indonesia Nomor 43 Tahun 2007 tentang Perpustakaan mengamanatkan bahwa perpustakaan merupakan institusi pengelola koleksi karya tulis, karya cetak, dan atau karya rekam secara professional dengan sistem yang baku guna memenuhi kebutuhan pendidikan, penelitian, pelestarian informasi, dan rekreasi para pemustaka. Sistem yang baku dan professional bisa diartikan pengolahan informasi dengan menggunakan teknologi informasi sebagaimana yang berlaku dalam sebuah perpustakaan digital (Repository).

Dalam perpustakaan digital, repository dapat diartikan sebagai tempat penyimpanan ratusan aplikasi atau file yang berupa kumpulan software-software yang dibuat khusus untuk suatu kepentingan para pengguna. Repository di sini bisa diartikan semacam gudang data sumber ilmu pengetahuan dan informasi yang sudah diupload melalui web. Bentuknya sangat fleksibel, bisa DVD atau server online. Adanya repository ini memungkinkan para pengguna untuk mengakses informasi lebih cepat dan bebas melalui internet dengan tanpa dibatasi oleh jarak, ruang, dan waktu. Pengembangan perpustakaan sebagai Knowledge Repository dapat dilakukan dengan cara :

1. Repository Institusional, dengan cara mengemas ulang informasi dengan mengalihmediakan semua hasil karya peneliti menjadi koleksi digital

2. Memperbanyak publikasi ilmiah dari hasil penelitian yang dilakukan oleh para peneliti di berbagai jurnal yang terakreditasi khususnya jurnal internasional

3. Melanggan online database yang beragam dari berbagai disiplin ilmu dengan menambah literatur E-Journal (electronic journal) internasional;

4. Menghimpun informasi dari penerbitan publikasi ilmiah khususnya yang dapat di akses melalui media internet

5. Mengembangkan aplikasi web dengan 'Library 2.0'yang mengupayakan adanya partisipasi pengguna perpustakaan dan learning commons, sehingga diharapkan adanya perbaikan terusmenerus yang berkelanjutan.

\section{PERANAN PUSTAKAWAN}

Pustakawan merupakan salah satu unsur SDM penunjang utama dalam penyelenggaraan perpustakaan karena pustakawan merupakan tenaga professional (brainware) yang bertugas menunjang perencanaan dan pelaksanaan proses pembelajaran di perpustakaan. Oleh karena itu, pustakawan harus mengubah paradigma dari information provider ke information access provider. Hal ini mengingat bahwa saat ini kemajuan teknologi telah menyebabkan ledakan informasi sekaligus mempermudah akses informasi, sehingga pustakawan harus menguasai Teknologi Informasi dan Komunikasi (TIK). Sedemikian besarnya peran pustakawan, maka pustakawan hendaknya selalu meningkatkan terus menerus (continuous improvement), baik kompetensi maupun kinerjanya di perpustakaan dalam melayani pemustaka.

Peranan pustakawan dalam menunjang pengembangan perpustakaan sebagai knowledge Repository menurut (Muttaqien, 2006) adalah :

1.Creation, pengetahuan makin berkembang dengan adanya transfer dan analisis dari tidak lagi dibatasi oleh ruang dan waktu serta keanggotaan pada suatu institusi. Siapapun orangnya, dari mana saja dapat memperoleh informasi/ pengetahuan yang dibutuhkan jika yang bersangkutan mempunyai akses ke internet.berbagai pihak. Perpustakaan tidak menciptakan pengetahuan, tetapi memiliki andil dalam proses berkembangnya pengetahuan. Hal ini tidak akan terjadi jika tidak ada orang yang mengelola perpustakaan (pustakawan). Jadi, bila dihubungkan dengan konsep creation, pustakawan harus mampu menjadi pemicu perkembangan pengetahuan, Pustakawan yang profesional akan mendukung ke arah berkembangnya pengetahuan dan penelitian, dengan cara selalu meng update koleksi dari berbagai media informasi (terutama sumber internal yang di-digitalkan) dan memfasilitasi alat telusur yang user friendly. 
2. Utilization, dalam hal ini adalah tingkat keterpakaian koleksi perpustakaan. Saat ini terjadi tren penurunan keterpakaian koleksi tercetak, contoh kasus ini adalah yang alami perpustakaan Fakultas Kedokteran UGM (Sukirno et. al., 2012). Untuk menanggulangi kondisi ini pustakawan harus dapat mendorong pengembangan Knowledge Repository, jika Knowledge Repository dapat berjalan dengan baik hal ini akan meningkatkan keterpakaian koleksi digital sehingga dapat menutupi berkurangnya keterpakaian koleksi tercetak.

3. Acquisition, adalah pengadaan informasi/koleksi, dalam hal ini koleksi berupa local content baik yang sudah dalam bentuk digital maupun masih bentuk tercetak. Untuk dapat menjaring semua informasi/koleksi internal institusi pustakawan sebaiknya mengembangkan jaringan informasi dengan perpustakaanperpustakaan lain yang mempunyai bidang sama.

4. Storing (penyimpanan), dalam repository koleksi dan data-data terkait disimpan dalam bentuk digital. Hal ini membutuhkan keahlian khusus untuk pemeliharaan dan pelestarian koleksi. Pemeliharaan dan pelestarian dalam lingkungan digital dapat dilakukan melalui beberapa cara: preservasi teknologi (hardwaredan software), penyegaran dan pembaharuan, migrasi dan format ulang, emulasi ('penyegaran" di lingkungan sistem), arkeologi data (penggalian data; misal karena bencana), dan alih media ke bentuk analog (digital ke microfilm) (Ramadhaniati, 2012).

5. Distribution/sharing, konsep ini menjelaskan bahwa harus ada proses distribusi pengetahuan pada repository. Artinya, bagaimana pustakawan dapat mendorong terjadi transfer informasi/pengetahuan yang ada dan dimiliki institusi ke pemustaka dilakukan secara efektif dan efisien.

6. Structure, yang dimaksudkan di sini adalah struktur transfer pengetahuan, atau struktur media yang digunakan sebagai media transfer pengetahuan. Berdasarkan konsep ini media yang digunakan harus menitikberatkan pada sumber informasi/pengetahuan bentuk digital, maka pustakawan harus men-digitalkan semua materi yang masih bentuk cetak dan akan dimasukkan sebagai koleksi repository dengan tetap memertimbangkan aspek hukum yang berlaku.

7. Technology, adalah alat dan atau cara yang digunakan dalam pengembangan repository. Oleh karena repository bertumpu pada teknologi digital, maka pustakawan harus menyediakan dan memahami sarana dan prasarana teknologi tersebut.

8. Measurement, konsep ini mengarah pada pengukuran secara kuantitif dan kualitatif untuk mengukur keberhasilan tujuan repository, membuat umpan balik dan melakukan tindakan yang diperlukan. Pengukuran dilakukan mulai dari tahap perencanaan sampai dengan repository berjalan serta dilakukan secara berkala dan konsisten.

9. Organizational design, masih banyak perpustakaan yang belum memasukkan perpustakaan digital dalam struktur organisasinya atau belum mempunyai sama sekali sehingga belum dapat menampilkan repository -nya. Agar dapat berjalan sebagaimana diharapkan repository dimasukkan dalam struktur organisasi resmi.

10. Leadership, konsep ini sangat berhubungan dengan sistem organisasi induk sehingga ada kepemimpinan kolektif yang berlaku untuk perpustakaan. Pemimpin diperlukan untuk menyatukan visi perpustakaan dalam mengembangkan repository, menegosiasikan dan menjalin kerja sama dengan pihak-pihak terkait untuk mewujudkan repository.

11. Culture, dalam hal ini adalah upaya pustakawan meng-'up date' pengetahuan serta menjadikan perilaku peningkatan pengetahuan sebagai budaya.terutama peningkatan kemampuan tentang teknologi komputer (digital). 


\section{KOMPETENSI PUSTAKAWAN}

Untuk mengatasi permasalahan dan tantangan yang semakin berat dan kompleks, dalam mendukung terwujudnya perpustakaan sebagai knowledge repository, mau tidak mau Pustakawan harus memiliki kompetensi profesional dan kompetensi pribadi. Murphy (1991) mendefinisikan pustakawan di perpustakaan khusus lebih spesifik dengan menyatakan bahwa seorang pustakawan di perpustakaan khusus mempunyai kompetensi khusus. Kompetensi khusus tersebut bersifat unik dan saling mempengaruhi satu sama lain, yaitu pengetahuan (knowledge), pemahaman (understanding), keahlian (skills), dan perilaku (attitudes). Kompetensi khusus dan unik tersebut termasuk di dalamnya penguasaan secara mendalam pengetahuan berbagai informasi khusus sesuai subyek spesialisnya, berbagai informasi atau pengetahuan baik tercetak maupun elektronik yang dapat mempertemukan user atau pengguna dengan informasi yang dibutuhkannya. Bottazzo (2005) menyatakan bahwa peran pustakawan atau information specialist di perpustakaan khusus yang telah mengaplikasikan teknologi informasi adalah (1) memahami dengan baik informasi yang dibutuhkan untuk organisasinya, (2) harus dapat memahami dan kemudian mengevaluasi sumber-sumber informasi yang dimiliki dan relevan dengan organisasinya serta sekaligus juga membina kerja sama informasi dengan sumber-sumber informasi tersebut, pustakawan harus menjadi promotor yang menentukan dalam organisasi untuk pengadaan materi informasi perpustakaan, indeksing, berita dan aktivitas lain.

Sidang tahunan Special Libraries Association (SLA) pada tahun 1996, menyatakan perpustakaan khusus memerlukan pustakawan yang memiliki kemampuanatau kompetensi khusus. Kompetensi khusus tersebut yaitu kompetensi profesional dan kompetensi personal.Kompetensi profesional menyangkut pengetahuan yang dimiliki pustakawan khusus dalam bidang sumberdaya informasi, akses informasi, teknologi, manajemen dan riset, serta kemampuan untuk menggunakan bidang pengetahuan sebagai basis dalam memberikan layanan perpustakaan dan informasi. Kompetensi personal adalah keterampilan atau keahlian, sikap dan nilai yang memungkinkan pustakawan bekerja secara efisien, menjadi komunikator yang baik. karir pribadi memiliki keterampilan bisnis dan menciptakan peluang baru, mengakui nilai profesional kerja sama dan kesetiakawanan, dan bersifat fleksibel atau luwes dan bersikap positif.

Pustakawan digital adalah spesialis informasi profesional, dapat mengelola perpustakaan digital, mengkombinasikannya secara profesional untuk perencanaan, data mining, penggalian pengetahuan, layanan rujukan digital, layanan informasi digital, representasi informasi, ekstraksi, distribusi informasi, koordinasi, www berbasiskan internet, akses dan penelusuran multimedia. (Nanan khasanah, 2008) Dari uraian tersebut bisa disimpulkan bahwa pustakawan memainkan peran yang dinamis, kecepatan dan ketepatan dalam mengakses informasi yang dibutuhkan oleh pemakai untuk keperluan pendidikan dan pelatihan serta pengembangan diri. Tugas dari seorang pustakawan digital tidak berbeda dengan tugas seorang pustakawan pada bagian pengolahan bahan pustaka, hanya saja pada pustakawan digital lebih menyiapkan informasi yang dibutuhkan pemakai melalui penyimpanan digital dan preservasi digital, membuat katalog dan membuat klasifikasi dengan cara digital. Untuk mengelola perpustakaan digital, seorang pustakawan harus mempunyai pengetahuan dan keterampilan digital, diantaranya adalah kemampuan internet. baik serta cermat mempermudah pengguna dalam mendapatkan data dan informasi yang diperlukan.

\section{KOMPETISI PERPUSTAKAAN}

Standar perpustakaan khusus yang ditetapkan oleh Badan Standarisasi Nasional, dimaksudkan untuk menetapkan dasar pengelolaan perpustakaan khusus instansi pemerintah, meliputi status organisasi, jasa dan sumber daya yang terdiri dari sumber daya manusia, gedung dan anggaran. Standar ini berlaku pada perpustakaan khusus yang dibentuk oleh dan menjadi bagian dari instansi 
pemerintah. Perpustakaan khusus instansi pemerintah merupakan satuan organisasi perpustakaan yang dipimpin oleh seorang kepala perpustakaan. Kepala perpustakaan dalam menjalankan tugasnya dibantu unit layanan pembaca dan unit layanan teknis Jumlah sumber daya manusia sekurangkurangnya 3 orang, terdiri dari 1 (satu) kepala perpustakaan, 1 (satu) tenaga pustakawan dan 1 (satu) tenaga teknis. Perbandingan SDM adalah 1:2 yaitu 1 (satu) tenaga pustakawan, 2 (dua) tenaga teknis.

Pengembangan sumber daya manusia Perpustakaan memberikan kesempatan untuk pengembangan sumber daya manusia secara terprogram melalui pendidikan formal, nonformal dan pengembangan di bidang kepustakawanan dan penjenjangan kedinasan. Perpustakaan menerapkan prinsip-prinsip manajemen : perencanaan, pengorganisasian, penataan staf, pengarahan, pengawasan, penganggaran, dan pelaporan.

Kualifikasi kepala perpustakaan adalah seorang tenaga profesional, sekurangkurangnya berijazah strata 1 (S1) di bidang ilmu perpustakaan atau $\mathrm{S} 1$ bidang lain ditambah dengan diklat penyetaraan bidang perpustakaan. Tenaga teknis yang memiliki keahlian sesuai dengan bidang dan profesinya yang bertugas menunjang tugas pokok dan fungsi perpustakaan, seperti tenaga teknis komputer, audio visual, ketatausahaan.

Koleksi dasar yang harus dimiliki oleh perpustakaan khusus adalah sekurangkurangnya 1.000 judul dalam bidang kekhususannya. Sekurang-kurangnya $80 \%$ koleksinya terdiri dari subyek/disiplin ilmu tertentu sesuai dengan kebutuhan instansi induknya. Perpustakaan menyediakan koleksi terbitan dari dan tentang instansi induknya. Perpustakaan melanggan minimal 10 judul majalah yang berkaitan dengan kekhususan instansi induknya.

Sarana dan prasarana perpustakaan khusus adalah segala sesuatu yang menunjang terselenggaranya suatu kegiatan perpustakaan, meliputi gedung, mebeler perpustakaan, dan infrastruktur teknologi informasi seperti, komputer, printer dan fasilitas internet yang memadai. Perpustakaan harus memiliki gedung sendiri atau sekurang-kurangnya memiliki ruangan sendiri secara terpisah dari ruangan kegiatan perpustakaan. Perpustakaan menempati ruang (gedung) sendiri dan menyediakan ruang untuk koleksi, staf dan penggunanya dengan luas sekurang-kurangnya $100 \mathrm{M}^{2}$.

Perpustakaan menerapkan teknologi informasi dan komunikasi dalam pengadaan dan pengorganisasian materi perpustakaan, layanan sirkulasi dan informasi termasuk akses internet. Layanan yang diberikan perpustakaan khusus instansi pemerintah meliputi :

- layanan baca di tempat;

- layanan sirkulasi;

- layanan kesiagaan informasi;

- layanan referensi;

- layanan penelusuran informasi;

- layanan bimbingan pengguna.

Untuk dapat melaksanakan kegiatan perpustakaan harus mempunyai anggaran yang secara rutin tersedia melalui anggaran badan induk.atau dapat menggali sumber anggaran lain yang sah dan tidak mengikat. SNI perpustakaan ini sudah di adopsi kedalam permen KP No. 8 Tahun 2015 tentang penyelenggaraan perpustakaan di lingkup Kementrian Kelautan dan Prikanan. Dengan $\begin{array}{llll}\text { adanya permen } & \text { KP } & \text { No.8 Tentang }\end{array}$ penyelenggaraan perpustakaan di lingkup Kementrian Kelautan dan Perikanan merupakan dukungan besar untuk terbentuknya perpustakaan yang berstandar SNI di KKP.

\section{KONDISI PERPUSTAKAAN DAN PUSTAKAWAN KKP}

Perpustakaan di lingkup KKP berada di satker- satker dan dibawah koordinasi Pusat Data dan Informasi (PUSDATIN). Perpustakaan di pusdatin merupakan salah satu unit kerja dibawah seksi dokumentasi dan publikasi jadi secara struktural ada dibawah eselon IV. Perpustakaan di pusdatin cukup luas dan sudah memenuhi standar SNI, akan tetapi perpustakaan di satker-satker di lingkup KKP kondisinya masih memprihatinkan baik secara struktural maupun standar. Kondisi 
perpustakaan di satker - satker lingkup KKP hanya ada sebagian kecil saja yang sudah memenuhi standar SNI sedangkan sebagian besar masih jauh dari standar. Keadaan dan fasilitas perpustakaan juga dari setiap satker berbeda-beda, ada yang sudah memiliki ruangan tersendiri tetapi masih banyak yang bergabung dengan ruangan kerja lain. Sarana perpustakaan ada yang sudah dilengkapi dengan sarana komputer dan sudah menggunakan program untuk pengolahan informasi ( $\mathrm{TI}$ ) ada juga yang belum. Fasilitas ruangan (gedung) dan sarana lain juga sangat berbeda di setiap satker begitu juga dengan sarana dan prasarana yang lain seperti ruang baca dan staf juga lemari untuk koleksi dlsb, masih sangat jauh dari standar perpustakaan khusus yang telah ditetapkan.

Pustakawan di lingkup kementrian kelautan dan perikanan bekerja di perpustakaan perpustakaan di seluruh satker KKP. Menurut data yang diperoleh dari pusat data dan informasi (PUSDATIN), perpustakaan di lingkup KKP jumlah tenaga yang bekerja di perpustakaan ada 110 orang. Pengelola perpustakaan ada yang sudah mempunyai jabatan fungsional pustakawan dan ada yang belum mempunyai jabatan fungsional pustakawan. Dari jumlah tersebut hanya ada 19 orang saja atau kurang dari $10 \%$ yang telah mempunyai jabatan fungsional pustakawan. Disamping itu juga ada pustakawan atau tenaga pengelola perpustakaan yang berlatar belakang ilmu perpustakaan akan tetapi diberi tugas lain di luar perpustakaan yang bobotnya lebih besar dari tugas di perpustakaan. Keadaan ini sangat tidak mendukung untuk pengembangan perpustakaan di lingkup KKP. Pengelola perpustakaan akan lebih baik apabila dikelola oleh seorang professional di bidangnya tentunya seorang yang berlatar belakang pendidikan di bidang perpusdokinfo atau menguasai ilmu teknologi informasi. Pengelola perpustakaan yang berlatar belakang pendidikan sesuai bidangnya dan ditunjang dengan jabatan professional akan lebih produktif dalam bekerja.

\section{PERMASALAHAN}

Permasalahan yang timbul dalam membangun knowledge repository KKP adalah karena kondisi perpustakaan tempat pustakawan bekerja secara struktural belum kuat. Begitu juga dari segi sarana prasarana maupun kualitas atau kompetensi SDM yang bekerja di perpustakaan masih dibawah standar, secara garis besar ada beberapa masalah yang masih harus dipecahkan sbb:

1. Kedudukan Perpustakaan di lingkup KKP secara struktural di pusat masih rendah dan terutama di satker-satker.

2. Kondisi perpustakaan sebagian besar masih dibawah standar SNI perpustakaan khusus.

3. Permen KP No.8 tentang penyelenggaraan perpustakaan di lingkup KKP belum disosialisasikan dan diimplementasikan.

4. Kompetensi SDM atau pustakawan masih belum memadai untuk sebuah perpustakaan digital.

5. Pustakawan mendapat tugas rangkap / pekerjaan lain yang banyak menyita waktu di luar pekerjaan perpustakaan.

6. Belum ada perhatian khusus dari pimpinan untuk meningkatkan karier pustakawan.

\section{PEMECAHAN MASALAH}

Masalah atau kendala yang ada dalam pelaksanaan knowledge repository di KKP dapat dipecahkan apabila ada perhatian khusus dari para pengambil kebijakan di KKP untuk menjadikan perpustakaan sebagai yang dipentingkan terutama dalam pengelolaan informasi atau knowledge manajemen repository KKP. Kementerian Kelautan dan Perikanan telah berusaha dalam menigkatkan peran perpustakaan terbukti dengan adanya Permen KP No. 8 tentang penyelenggaraan perpustakaan di lingkup KKP, namun sayangnya permen KP ini belum disosialisasikan dan dimplementasikan dengan baik beberapa alternative pemecahan masalah ini perlu kiranya dipertimbangkan :

1. Memperkuat struktur organisasi perpustakaan dari mulai pusat sampai ke satker - satker 
2. Mengoptimalkan implementasi permen KP No. 8 Tahun 2014

3. Meningkatkan kegiatan forum Pustakawan KKP dengan mengadakan atau membentuk jaringan antar perpustakaan di lingkup KKP

4. Meningkatkan komunikasi antar pustakawan melalui kegiatan forum seperti, seminar /workshop /bimtek dlsb minimal 2 kali setahun.

5. Tidak memberikan tugas rangkap kepada pustakawan diluar pekerjaan perpustakaan.

6. Meningkatkan kompetensi pustakawan dengan memberikan kesempatan kepada pustakawan untuk mendapatkan pendidikan yang lebih tinggi (S2, S3) terutama dalam bidang manajemen perpustakaan dan teknologi informasi dan komunikasi.

\section{KESIMPULAN}

Peran pustakawan dalam mendukung knowledge manajemen repository Kelautan dan Perikanan akan dapat dilaksanankan secara optimal apabila ada dukungan dari pengambil kebijakan di KKP. Dukungan yang diharapkan antara lain dengan memperkuat stuktur organisasi perpustakaan dari tingkat pusat sampai ke satker-satker. Kemudian mengoptimalkan pelaksanaan permen KP No. 8 tahun 2014 tentang penyelenggaraan perpustakaan di lingkup KKP, memberikan peluang kepada pustakawan untuk mendapat pendidikan yang lebih tinggi terutama dalam bidang teknologi informasi dan komunikasi, meningkatkan komunikasi antar pustakawan dengan membentuk jaringan perpustakaan dan mengefektifkan kegiatan forum komunikasi pustakawan lingkup KKP.

\section{DAFTAR PUSTAKA}

Badan Standarisasi Nasional, 2009. Standarisasi Nasional (SNI 7496:2009), Perpustakaan Khusus Instansi Pemerintah. Jakarta

Fatmawati, Endang (2009)."Kesiapan Pustakawan UNDIP untuk mendukung
UNDIP sebagai Universitas Bertaraf Internasional". VISI PUSTAKA Volume 11 Nomor 2 Agustus 2009

Indonesia, Undang-Undang Nomor 43 Tahun 2007 Tentang Perpustakaan Nasional RI. Perpustakaan Nasional RI, Pedoman Umum Penyelenggaraan Perpustakaan Khusus, 2000

Kamil, Harkrisyati (2005). "Peran Pustakawan Dalam Manajemen Pengetahuan", Jurnal Studi Perpustakaan Indonesia Vol.4 No.1,hal. 19-22.

Kementrian Kelautan dan Perikanan RI, Peraturan Menteri Kelautan Dan Perikanan Republik Indonesia Nomor 8/PERMENKP/2014 Tentang Pedoman Penyelenggaraan Perpustakaan Kusus di Lingkungan Kementrian Kelautan dan Perikanan.

Muttaqien, Arip (2006). Membangun Perpustakaan Berbasis Konsep Knowledge Management: Transformasi MenujuResearch College dan Perguruan Tinggi Berkualitas Internasional. http://www.lib.ui.ac.id/files/Arip_Muttaqien. pdf, akses 24 April 2015.

Suwardi, (2014). Peran Pustakawan Dalam Pengembangan Institusional Repository: Sebuah Tantangan "Visi Pustaka Vol.16 No. $1: 78-85$

Wicaksono, Hendro (2005) "Manajemen Pengetahuan Vs Manajemen Informasi", Tempo 17 Feb 2005 